\title{
EFICIÊNCIA PROCESSUAL NO JUDICIÁRIO: APLICAÇÃO DO DEA EM VARAS ÚNICAS NO RIO GRANDE DO NORTE
}

\author{
ARAÚJO, Richard Medeiros de ${ }^{1}$ \\ DIAS, Thiago Ferreira ${ }^{2}$ \\ GOMES, Jean Fernandes ${ }^{3}$
}

\begin{abstract}
RESUMO: Este trabalho busca mensurar a eficiência das varas únicas do Poder Judiciário utilizando de técnicas não paramétricas, Análise Envoltória de Dados, as quais viabilizam a construção de benchmarks (fronteira da eficiência) para comparar a eficiência entre as unidades judiciárias. O Tribunal de Justiça do Rio Grande do Norte pode ser visto como um prestador de serviços judiciais e o seu desempenho avaliado a partir de uma definição adequada dos insumos e dos produtos de cada segmento. A partir das bases de dados cedidas são analisadas a Justiça Potiguar, referentes ao período de 2011 a 2013, sob a ótica força de trabalho e celeridade processual em conjunto com a carga de trabalho. O estudo envolveu 49 varas únicas, distribuídas em diferentes municípios do Estado do Rio Grande do Norte. O procedimento de análise foi estruturado por fases. Os resultados apontam sob a ótica, força de trabalho, o papel importante de uma instituição pública em ter mais servidores efetivos no seu quadro funcional para elevar o nível de eficiência dos seus processos e sob ótica, celeridade processual e carga de trabalho, os resultados informam que as comarcas ou varas de menor volume processual tende a ter um nível de eficiência maior que comarcas de maior envergadura.
\end{abstract}

Palavras-chave: Judiciário. DEA. Eficiência. Rio Grande do Norte

SUMMARY: This paper seeks to measure the efficiency of the few sticks of the judiciary using nonparametric techniques, data envelopment analysis, which enable the construction of benchmarks (the efficient frontier) to compare efficiency between judicial units. The Rio Grande do Norte Court can be seen as a provider of legal services and their performance evaluated from a proper definition of inputs and products of each segment. From the transferred databases are analyzed Potiguar Justice for the period 2011-2013, from the perspective workforce and speedy trial together with the workload. The study involved only 49 poles, distributed in different municipalities of Rio Grande do Norte. The analysis procedure was structured phases. The results show the perspective, the workforce, the role of a public institution to have more effective servers on its staff to raise the level of efficiency of its processes and in optics, promptness and workload, the results report the regions or procedural minor amount rods tends to have a higher level of efficiency than the regions of greater weight.

\section{Keyword:}

\section{INTRODUÇÃO}

Em seu preâmbulo, a Constituição de 1988, institui o Estado Democrático de Direito destinado a assegurar o exercício dos direitos sociais e individuais, a liberdade, a segurança, o bem-estar, o desenvolvimento, a igualdade e a justiça como valores supremos de uma sociedade fraterna, pluralista e sem preconceitos, fundada na harmonia social (BRASIL, 1988). Dessa forma, a Constituição Federal de 1988 reconheceu os direitos de todos os cidadãos perante o Estado, o que se dá através da máquina administrativa. Portanto, o Estado se obriga a garantir ao cidadão a prática de seus direitos, em nome de um Estado Democrático, e para tanto necessita da eficiência em todos os âmbitos da gestão pública.

Com objetivo de garantir ao cidadão a prática de seus direitos, o artigo 37 da Constituição Federal de 1988 (EC 88) declara que a administração pública direta e indireta de qualquer dos Poderes da União,

\footnotetext{
${ }^{1}$ UFRN/UNIFACEX

${ }^{2}$ Doutor em Administração e professor do PPGP/UFRN

${ }^{3}$ Mestre em Gestão Pública PPGP/UFRN
} 
dos Estados, do Distrito Federal e dos Municípios obedecerá aos princípios de legalidade, impessoalidade, moralidade, publicidade e eficiência (BRASIL, 1988).

Entretanto, para dar respaldo jurídico para a concretização de mudanças que se faziam imprescindíveis para a modernização da máquina administrativa do Estado brasileiro, Alexandrino (2012) frisa que a promulgação da Emenda Constitucional $n^{\circ} 19$ de 04/06/98, garanta que a gestão da coisa pública seja cada vez menos burocrática e atinja seus objetivos introduzindo o princípio da eficiência no rol dos princípios que regem a Administração Pública. O princípio da eficiência, como, também, alguns princípios elencados na Constituição Federal que se enquadra em ferramentas democráticas, compreende um conjunto de direitos e garantias em detrimento daqueles que integram o processo, se caracterizando assim como uma exaltação do Estado Democrático de Direito nos litígios processuais. E este direito compreende a sua prestação eficiente, justa e célere, por meio da efetiva aplicação do direito.

A partir da Constituição de 1988, e principalmente, após a promulgação da Emenda Constitucional nº 19/98, o Poder Judiciário e as mudanças que nele se fazem necessárias vem sendo objeto de intenso debate, não só em função dos aspectos materiais de seu funcionamento, mas principalmente pelo cumprimento do exercício da democracia brasileira, proporcionando um amplo debate sobre a eficiência nos recursos da máquina pública.

Com isso, a reforma do Poder Judiciário, que tramitou no Congresso Nacional, por mais de uma década, e que foi finalizada, através da Emenda Constitucional de nº 45, de 2004 trouxe uma reforma minuciosa, interligada e, sobretudo, inovadora, que traçasse novos contornos ao perfil do Judiciário e trouxesse novos instrumentos que de fato viabilizem a prática desta reforma (PAES, 2003).

Neste sentido, vale dizer que a Reforma Constitucional do Poder Judiciário introduziu de modo expresso no rol de direitos fundamentais o princípio da duração razoável do processo, e o fez mediante a inserção do inciso LXXVIII, no artigo $5^{\circ}$ da Constituição Federal, que aduz: "a todos, no âmbito judicial e administrativo, são assegurados a razoável duração do processo e os meios que garantem a celeridade e tramitação". Dessa forma, a reforma do Judiciário faz alusão, ainda que indiretamente, a um dos princípios constitucionais que vigoram e são aplicados ao referido Poder, o princípio da eficiência.

Percebe-se, desde as reformas em curso na organização e no funcionamento do Poder Judiciário, uma tendência na administração pública à adoção de instrumentos de gestão visando à medição do desempenho, bem como do incremento de sua eficiência e resultados. Na tentativa de adequação a este cenário, tornou-se comum a elaboração e o uso de sistemas de mensuração que se propõem a conhecer melhor seus desempenhos organizacionais (ARAÚJO; BESSA, 2010).

Corroborando com a ideia de quantificar a eficiência, no campo acadêmico, nos últimos anos foram desenvolvidos alguns estudos para mensurar a eficiência de diferentes tipos de instituições, das mais diversas atividades, em diversos contextos, conforme a exemplo de Nogueira et al (2011), Souza (2012), Kuiaski (2001) e Schwengber (2006).

Diante deste contexto questiona-se: quais são os níveis de eficiência das varas únicas das Comarcas de primeira, segunda e terceira entrância, do Tribunal de Justiça do RN?

Assim, este estudo avalia as comarcas que estão sob as mesmas regras institucionais, ou seja, considerar enquanto unidade de observação não a Justiça Estadual como um todo - composta por centenas de serventias e comarcas -, mas as varas únicas, das comarcas de primeira, segunda e terceira entrância, do Tribunal de Justiça do RN.

O Tribunal de Justiça do Rio Grande do Norte, especificamente falando, através de seus gestores tem o dever do conhecimento e ao cumprimento da missão do Poder Judiciário Estadual. Por outro lado os magistrados e servidores têm também a obrigação do conhecimento de sua produtividade e eficiência. 
Como saber, comparando-se duas ou mais unidades judiciárias, se a produção está satisfatória, se o desempenho está eficiente, este será o foco do trabalho.

\section{REVISÃO DA LITERATURA}

\subsection{Evolução da Administração Pública e Eficiência}

O Estado possui funções importantes para a sociedade, em especial, políticas, sociais e econômicas. Deve atender aos anseios dos cidadãos com prestação de serviços nas áreas da saúde, educação, segurança, seguridade social, dentre outros. Essas atividades decorrentes do papel do Estado são realizadas por meio da administração pública, que engloba um conjunto de serviços necessários para a realização de tais atividades. Portanto, com a finalidade de implementar as atividades decorrentes do papel do Estado, a administração pública no Brasil tem passado por um processo de modernização, intitulado na literatura como: Nova Gestão Pública.

No Brasil, a modernização da gestão pública iniciou na década de 1930, a primeira reforma administrativa. O modelo se pautava no desenvolvimento da administração com base no modelo burocrático weberiano e veio como alternativa superior ao modelo de administração patrimonialista, herança do modelo administrativo, no período do Brasil colônia (WARHLICH,1984).

Por meio de uma significativa reforma de Estado, o Presidente Vargas buscou romper com o modelo de Estado patrimonial, iniciando a construção de um aparato institucional visando não apenas centralizar o poder, mas também ampliar a capacidade de intervenção estatal, a partir da adoção de medidas em prol da racionalização do serviço público (NUNES,1997).

E foi neste contexto que Vargas inaugurou a primeira reforma administrativa brasileira, que teve na criação do Departamento Administrativo do Serviço Público (DASP), em 1938, sua principal marca.

O DASP era o órgão central do sistema de controle da administração pública brasileira e a peçachave para a constituição de uma burocracia profissional, aos moldes weberianos. As medidas introduzidas por Getúlio desde 1930, e que culminaram na constituição do DASP em 1938, criaram os alicerces para a formação de um corpo burocrático que dava seus primeiros passos em direção à profissionalização e à meritocracia, pré-requisitos essenciais para alcançar a eficiência do aparato da administração pública e desestruturar as bases do modelo de Estado oligárquico (ABRÚCIO, 2007).

Rezende (2004) informa que a reforma administrativa conduzida pelo DASP, também, foi responsável pela criação de unidades administrativas descentralizadas da burocracia federal, as chamadas autarquias: entidades com certo grau de autonomia e flexibilidade, responsáveis por cumprir determinadas funções na prestação de serviços.

Bresser-Pereira (1996), ao mencionar a reforma administrativa de Vargas, destaca sua iniciativa em inaugurar a descentralização dos serviços públicos, identificando na primeira reforma administrativa brasileira uma característica da administração pública gerencial, diz:

Já em 1938 temos um primeiro sinal da administração pública gerencial, com a criação da primeira autarquia. Surgia então a ideia de que os serviços públicos na 'administração indireta' deveriam ser descentralizados e não obedecer a todos os requisitos burocráticos da 'administração direta' ou central (pág 6). 
Com isso, a modernização Daspiana deixa de ser resultado das ações do órgão e passa a ser uma forma administrativa, presente basicamente na administração indireta, que se expande e continua na linha do insulamento burocrático.

Mesmo assim, Nunes (1997) afirma que nem sempre era possível livrar a gestão da influência do clientelismo, e tampouco se levou adiante qualquer processo de reforma global. Por esta razão, o presidente Juscelino Kubitschek procurou resolver o dilema do desempenho pela chamada administração paralela, fundamental no seu Plano de Metas.

Na segunda reforma administrativa, que aconteceu no período do Estado autoritário, entre 1960 e 1964, foi conhecida como reforma desenvolvimentista. Estas reformas não dispensaram o equilíbrio fiscal, embora a ênfase se desse no bem-estar de modo integrado à responsabilidade fiscal. A eficiência é enfocada na perspectiva de mudanças estruturais e não só na redução de despesas. As transformações são voltadas para a redução do déficit institucional, fortalecimento da governança, aumento da eficiência, transparência e participação (BRESSER PERREIRA, 1998).

Entretanto, ainda, predominava a administração pública burocrática, os problemas decorrentes da administração paralela se acentuaram e os conflitos políticos do período 1961-64 não permitiram direcionar recursos para a sua resolução. E diante desse contexto, com o propósito de reduzir a rigidez burocrática que Constituição de 1967 modelou a estratégia da reforma do Estado, concretizada, através do Decreto-Lei n²00/1967 (REZENDE, 2004).

O Decreto-Lei n²00/1967 buscava introduzir na administração pública os conceitos do setor privado. Dessa forma, dividiu as estruturas da administração públicas em quatro categorias, diferenciadas pela autonomia decisória, pelas fontes de recursos e pela sua natureza jurídica (BRASIL, 1967).

Porém, as diretrizes do Decreto-Lei não funcionaram conforme o esperado, sendo incapaz de implantar mecanismos de aferição de performance, o que aumentou a fragmentação e a descentralização decisórias. E acrescentando-se, houve durante o regime militar, aumento de empresas públicas nos mais diversos setores econômicos, ampliando a inserção estatal na economia, o tamanho da burocracia federal e os gastos públicos (REZENDE, 2004).

Outro efeito do sistema administrativo fragmentado e baseado em burocracias setoriais insuladas durante o regime militar foi o aprofundamento da ligação entre setores da sociedade e a burocracia, fazendo com que ela se tornasse um meio para permitir a representação de interesses privados no regime autoritário, reforçando o papel da burocracia como arena política (CARDOSO, 1975).

Assim, a lógica fragmentada de funcionamento da máquina pública e do recrutamento setorial inibiu a consolidação de um sistema de mérito para o recrutamento e seleção do serviço público. Ou seja, o regime militar avançou em projetos desenvolvimentistas e colecionou êxitos em diversos setores, mas com uma grande expansão da estrutura e dos gastos governamentais (REZENDE, 2004).

O processo recente de reforma do Estado no Brasil começou com o fim do período militar. Era necessário corrigir os erros históricos da administração pública brasileira, muitos deles aguçados pelos militares, e encontrar soluções que dessem conta do novo momento histórico (ABRÚCIO, 2007).

Entretanto, Sena (2012) afirma que o foco principal da redemocratização foi tentar corrigir os erros cometidos pelos militares, ou seja, combater descontrole financeiro, a falta de responsabilização dos governantes e burocratas perante a sociedade, a politização indevida da burocracia nos estados e municípios, além da fragmentação excessiva das empresas públicas, com a perda de foco de atuação governamental, ao invés de dar importância à necessidade de se construir um modelo de Estado capaz de enfrentar os novos desafios históricos. 
No que se refere ao estabelecimento do regime jurídico único, Castro (2006) comenta que o nivelamento das carreiras públicas, que na prática eram completamente diferentes, estabeleceu uma rígida estabilidade e eliminou a autonomia das autarquias e fundações.

No que se refere à democratização do Estado, Abrúcio (2007) cita o exemplo dos Tribunais de Contas Estaduais, que pouco avançaram no controle dos governantes, quando não estiveram a eles vinculados de forma patrimonialista. A Constituição estabeleceu mecanismos de escolha dos Conselheiros que dificultam a sua autonomia, uma vez que o Executivo tem um enorme poder de interferir neste processo de nomeação, como também o Poder do Judiciário, com as nomeações dos ministros do Supremo Tribunal Federal e no âmbito da justiça estadual, nomeação dos desembargadores.

Dessa forma, a constituição de 1988 veio impregnada pelo engessamento burocrático extremo que, até hoje, influencia o comportamento e o cotidiano da gestão pública, bem como a interpretação para agir e decidir nos poderes (judiciário, executivo, legislativo), no Ministério Público e no Tribunal de Contas.

Diante desse quadro, o modelo de Estado e o seu aparelho administrativo passaram por uma profunda reformulação. Surge o modelo gerencial de administração pública, que busca a superação do modelo burocrático de gestão, mediante adoção de mecanismos que visam à excelência administrativa e ao foco no cidadão, ou seja, a capacidade de gestão torna-se o centro de discussão da Administração Pública, somada a significativas mudanças econômicas, tais como o ajuste fiscal e os procedimentos voltados para o mercado - a privatização e a desregulamentação, por exemplo.

Conforme Brulon (2012), o conjunto de concepções teóricas da Nova Gestão Pública surge, inicialmente, com um foco estritamente economicista de corte de custos e aumento de produtividade em um contexto de grave crise fiscal. Entretanto, Abrúcio (1998), defende que gerencialismo deve ser entendido como uma diversidade de respostas à crise do modelo burocrático weberiano, e que não existiria, assim, um modelo gerencial único, mas um conjunto de ideias em defesa da modernização do setor público.

Visando combater o engessamento burocrático imposto pela Carta Magna, as quais refletiram negativamente no funcionamento do aparelho estatal, iniciou em 1995, no governo do Presidente Fernando Henrique Cardoso, através do documento básico da reforma - o Plano Diretor da Reforma do Aparelho do Estado (PDRAE) - e robustecida com a aprovação da Emenda Constitucional no 19, de 4 de junho de 1998, cujos princípios continuam orientando a ação reformadora do governo, procurou-se definir as instituições e estabelecer as diretrizes para a implantação de uma administração pública gerencial no país (BRESSER-PEREIRA,2008).

Sena (2012) informa que com a efetividade da publicação da emenda constitucional no 19, ocorreu a mudança no regime, incluindo princípios e normas da Administração Pública, servidores e agentes políticos, controle de despesas e finanças públicas, efetivando as diretrizes propostas no PDRAE.

Abrúcio (2007) cita algumas mudanças, como por exemplo: Medidas que implicaram tetos para o gasto com funcionalismo, alterações no caráter rígido e equivocado do Regime Jurídico Único e introdução do princípio da eficiência entre os pilares do Direito Administrativo. Tais mudanças constituíram-se em peças essenciais na criação de uma ordem jurídica que estabeleceu parâmetros de restrição orçamentária e de otimização das políticas.

Entretanto, Abrúcio (2007) compreende que os caminhos da Gestão Pública Brasileira desde a redemocratização não pode ficar apenas na dinâmica diacrônica e cronológica. Houve uma série de ações inovadoras que não ficaram circunscritas a um dos períodos governamentais em análise. Seus impactos, entretanto, foram fragmentados e dispersos, sem que por isso fossem menos importantes. 
Em suma, a construção da Nova Gestão Pública deve ter uma série de características, como por exemplo: controle de resultados, transparência, accountability que tratam da importância de se ter instrumentos gerenciais e democráticos novos para combater os males que o Estado enfrenta no mundo contemporâneo. Se o formalismo e a rigidez burocrática devem ser atacados como problemas, alguns princípios do modelo weberiano podem, porém, constituir-se numa alavanca para a modernização, principalmente em prol da eficácia, eficiência e efetividade dos serviços públicos (SANO, 2003).

O princípio da eficiência foi inserido na Constituição com o objetivo de transformar o modelo de administração burocrática em administração gerencial, voltado precipuamente a garantir o papel regulador do Estado, a recuperação de sua capacidade financeira e administrativa, compatível com os avanços tecnológicos, mais ágil, descentralizada e voltada para o controle de resultados.

O modelo de administração gerencial aproxima a ação estatal das administrações privadas, que buscam sempre atingir resultados, minimizar os custos e reduzir os controles das atividades-meio. Esse controle é o grande responsável pela falta de agilidade e aumento dos custos da máquina estatal.

Sob a ótica do direito administrativo e constitucional, e da administração pública, a ideia de eficiência aproxima-se da de economicidade, princípio expresso no art.70, caput, da Constituição Federal de 1988, referente ao controle financeiro da Administração Pública. Pois, busca-se o atingimento de objetivos traduzidos por boa prestação de serviços, do modo mais simples, mais rápido, e mais econômico, melhorando a relação custo/benefício da atividade da Administração Pública. (ALEXANDRINO, 2012, p. 202).

Desta forma, o conceito do princípio de eficiência é econômico e não jurídico, pois ele orienta a atividade administrativa a alcançar os melhores resultados a menor custo e utilizando os meios que dispõe. Assim, devem-se buscar os melhores benefícios a menor custo possível.

A eficiência como princípio assume duas vertentes: a primeira é organizar e estruturar a máquina estatal para torná-la mais racional para que as necessidades da sociedade sejam alcançadas de forma mais satisfatória e a segunda, é regular a atuação dos agentes públicos buscando que esses tenham um melhor desempenho possível a fim de atingirem os melhores resultados.

Castro (2006) ressalta que a Emenda Constitucional 19 visou à boa administração, proporcionalmente bem-estar à população. Ela não foi um adereço. Ela permite que leis infraconstitucionais adotem mecanismos inovadores, sob a alegação de que estão de acordo com o Princípio da Eficiência.

E complementa, dizendo que a promulgação da emenda não significou um choque entre duas ciências. Ao contrário, representa um momento em que a Ciência Jurídica, sob a influência dos administradores públicos, produziu um texto condizente com as práticas modernas de gestão e, a partir daí, inclusive utilizando-se de conhecimentos jurídicos, a Ciência da Administração pôde produzir significativos avanços na condução das políticas públicas (CASTRO,2006).

E com intuito de aferir os gastos públicos, foi criado a Lei Complementar 101, de 04 de maio de 2000, contemplando no seu escopo, normas de finanças públicas direcionadas à responsabilidade fiscal onde no art.67, II, foi inserida conceitos de gestão fiscal com o propósito de resultar maior eficiência na alocação e execução dos gastos públicos e na transparência da gestão pública (BRASIL, 2000).

Morais (2012) afirma que o princípio da eficiência compõe-se, portanto, das seguintes características básicas:

a) Direcionamento da atividade e dos serviços públicos à efetividade do bem comum: promover o bem de todos, sem preconceitos de origem, raça, sexo, cor, idade e quaisquer outras formas de discriminação; 
b) Imparcialidade: salvaguardar o exercício da função administrativa e consequentemente, prosseguimento do interesse público da influência de interesses alheios à administração pública;

c) Neutralidade; o Estado é neutro se, na resolução de qualquer conflito de interesse, assume uma posição valorativa de simultânea e qual consideração de todos os interesses em presença;

d) Transparência: observância de fatores objetivos vislumbrando a eficiência da prestação de serviços, e consequentemente, afastando-se qualquer favorecimento ou discriminação;

e) Participação e aproximação dos serviços públicos da população: deverá existir participação e aproximação dos serviços públicos da população dos interessados na gestão efetiva dos serviços administrativos, de acordo com o princípio da gestão participativa, como verdadeiro desmembramento do princípio da soberania popular e da democracia representativa;

f) Eficácia: traduz na concretização de suas competências ordinárias e na execução e cumprimento dos entes administrativos dos objetivos que lhes são próprios;

g) Desburocratização: é evitar a burocratização da administração pública;

h) Busca da qualidade: é buscar otimização dos resultados pela aplicação de certa quantidade de recursos e esforços, incluída, no resultado a ser otimizado, primordialmente, a satisfação proporcionado ao cidadão (p. 28-30).

Entretanto, Modesto (2000) lembra que o princípio constitucional da eficiência é um princípio instrumental, como todos os princípios da administração pública.

Modesto (2000), complementa, afirmando que o princípio da eficiência pode ser percebido também como uma exigência inerente a toda atividade pública. Entende-se a atividade de gestão pública como atividade necessariamente racional e instrumental, voltada a servir ao público, na justa proporção das necessidades coletivas, temos de admitir como inadmissível juridicamente o comportamento administrativo negligente, contraprodutivo, ineficiente.

Assim, o princípio da eficiência, enquanto norma constitucional, serve de fonte para declaração de inconstitucionalidade de qualquer manifestação da Administração Pública contrária a sua plena e total aplicabilidade, ou seja, esse princípio pretende resolver, principalmente, o peculiar defeito da Administração Pública na prestação dos serviços públicos que é analisar a eficiência da administração (MELLO,2005).

A sociedade vem pressionando os governos a buscarem maior eficiência, efetividade e transparência de gestão. Neste contexto, expansão das políticas públicas e de contenção de gastos públicos a administração pública brasileira caminha com a finalidade de produzir mais com menos. Mediante contexto de mudanças, reformas vêm sendo implantadas nos órgãos do Poder Executivo, Legislativo e do Poder Judiciário (BRESSER-PEREIRA, 1999).

O Estado brasileiro, em acordo com os movimentos de reformas ocorridos em países desenvolvidos vem introduzindo novas práticas na gestão pública seguindo uma tendência denominada Nova Gestão Pública (ABRÚCIO, 2007).

A Constituição Federal de 1998, visando, principalmente, evitar o arbítrio e o desrespeito aos direitos fundamentais do ser humano, previu a existência dos Poderes do Estado e da Instituição do Ministério Público, independentes e harmônicos entre si, repartindo entre eles as funções estatais e prevendo prerrogativas e imunidades para que bem pudessem exercê-las, bem como criando mecanismos de controle recíprocos, sempre como garantia da continuidade do Estado democrático de Direito.

Vale salientar, que objetivos iniciais da célebre separação de poderes tinham como finalidade a proteção da liberdade individual em oposição a um governante poderoso (ABRÚCIO, 2007). 
Nesta linha, Nogueira et al (2011) ressaltam que a ampliação da garantia de direitos fundamentais e a extensão do acesso a novos atores políticos quanto à possibilidade de contestação da inconstitucionalidade de leis, ambas conferidas pela Constituição Federal de 1988, intensificaram a procura pelos serviços do Poder Judiciário no Brasil, acarretando a necessidade por significativas mudanças na natureza administrativa deste Poder.

Devido à autonomia e independência, conquistada pela Carta Magna, o Poder Judiciário desenvolve uma série de atividades administrativas de suporte à jurisdição, em grande parte, semelhantes às atividades administrativas dos outros poderes, a exemplo de elaboração de orçamentos, empenhos, folhas de pagamento, licitações, edificações e a gestão processual. Mas é certo que a busca por eficiência na gestão processual em muito depende de como se administra o fluxo de processos nas unidades jurisdicionais, por exemplo: as varas, secretarias e gabinetes do Judiciário.

Em se tratando de atividade de caráter muito mais administrativo que jurisdicional, é certo que deve receber o comando da eficiência, razão pela qual entende que, também, se aplica a norma do art. 37 da Constituição Federal.

Por isso, discutir a eficiência, eficácia e os resultados do desempenho do processo de gestão do poder judiciário, torna-se importante, tendo em vista as críticas relativas à morosidade da justiça. No âmbito dos movimentos de transparência da ação pública pensar como avaliar a qualidade de certas atividades do setor público, como o Poder Judiciário, ganha mais relevância e interesse (ARAUJO E BESSA, 2010).

Diante deste contexto, o tema da gestão pública voltada para resultados torna-se central, a partir das décadas de 1980 e 1990. O debate sobre as reformas estruturais consideradas necessárias passa a dar ênfase a aspectos responsáveis por promover otimização de procedimentos de um órgão ou poder público, visando melhorias no serviço que estes se designam a prestar ao cidadão (NOGUEIRA et al, 2011).

Com isso, a Emenda à Constituição n. ${ }^{\circ}$ 45/04, conhecida como Reforma do Judiciário, introduziu significativas modificações a Carta Magna do Estado. Esta legislação infraconstitucional teve como finalidade de proporcionar uma administração jurisdicional mais eficiente, com vistas a garantir o acesso à justiça e a razoável trâmite processual.

Hess (2010) destaca que a Reforma do Judiciário possui quatro grandes ordens:

a) Estruturais do Judiciário - informatização, que necessita ser implementada; virtualização dos procedimentos e instrumentalização dos atos judiciais e m comunicação com os operadores do Direito;

b) Institucionais - julgamentos de repercussão geral, por decisão de recurso extraordinário de matéria constitucional, Súmulas impeditivas de recursos, súmulas vinculantes dos Tribunais de Superposição e regulamentação administrativa por decisões do Conselho Nacional da Magistratura;

c) Procedimentais - legislação complementar do Estatuto da Magistratura e ordinária federal para celeridade do processual, mediação e conciliação;

d) Recursos humanos - mudança do operador do Direito, escolas de magistratura com cursos para aperfeiçoamento e promoção por merecimento, limitação de faculdades de Direito e exigência de experiência, e cursos de ingresso nas provas da Ordem dos Advogados do Brasil e concursos públicos (p. 214).

Portanto, a Reforma do Judiciário, seguiu a classificação da reforma da administração pública proposta por Bresser-Pereira (2008), devendo o modelo gerencial ser construído aproveitando as qualidades do modelo burocrático, como forma de preservar suas conquistas. Com isso, será possível oferecer à sociedade brasileira um serviço público com elevado grau de eficiência e de eficácia. 
Dessa forma, tal Emenda Constitucional, destaca Renault (2005), representa um rico processo de reflexão, envolvendo juízes, promotores, defensores públicos, advogados, acadêmicos e a sociedade civil, buscando um sistema judicial funcional, acessível e racional.

Segundo Renault (2005), as principais inovações que a EC n5/2004 traz consigo são:

a) Eficiência e celeridade do Judiciário - Instituição da súmula vinculante e da repercussão geral como requisito necessário do recurso extraordinário decorre do reconhecimento, agora expresso no rol de direitos fundamentais do cidadão, do direito a um processo judicial e administrativo célere. A utilização responsável desses instrumentos poderá ser importante para inibir a litigância protelatória, especialmente aquela realizada pelo poder público, que responde por grande volume de processos na Justiça.

b) Autonomia e independência dos magistrados - É aspecto fundamental da reforma a afirmação dos princípios constitucionais da autonomia e independência dos magistrados. As principais inovações relativas a esse princípio são as que tratam da autonomia financeira do Poder Judiciário, do estabelecimento de critérios unificados para ingresso na magistratura e no Ministério Público e da instituição da quarentena para o exercício da advocacia por parte dos juízes depois de exercerem essa atividade.

c) Funções essenciais e acesso à Justiça - O fortalecimento das funções da Justiça definidas na Constituição Federal como essenciais é condição necessária para o fortalecimento do Poder Judiciário. Nesse sentido, a concessão de autonomia às defensorias públicas foi um passo fundamental para a solidificação de políticas responsáveis de acesso à Justiça no País.

d) E por fim, estabeleceu , como órgão de cúpula administrativa do Poder Judiciário, o Conselho Nacional de Justiça - CNJ, porém sem atribuições jurisdicionais, concedendo ao CNJ a atribuição de realizar o controle da atuação administrativa e financeira do Poder Judiciário e do cumprimento dos deveres funcionais dos juízes, estabelecendo constitucionalmente, porém de forma exemplificativa, suas mais importantes atividades, que poderão ser acrescidas pelo Estatuto da Magistratura (págs132-133).

Pode-se, assim, observar que as inovações que a EC n $45 / 2004$, interferiu em diversos pontos, desde a organização estrutural do Poder Judiciário, até questões ligadas à competência dos órgãos jurisdicionais, como também, ampliou o acesso à justiça quando dotou de maior estrutura as funções essenciais à justiça, aparelhando a Advocacia, Ministério Público e Defensoria Pública, visando, com isso, oferecer à sociedade brasileira, uma justiça mais célere e transparente. Em relação atuação do Conselho Nacional de Justiça - CNJ, Alexandrino (2012) orienta para duas importantes atribuições: O controle da atuação administrativa e financeira do Poder judiciário; O controle do cumprimento dos deveres funcionais dos juízes e dos serventuários da justiça.

Com isso, Emenda Constitucional de n. ${ }^{\circ} 45$, de 2004 buscou estabelecer o efetivo controle administrativo pautado na legalidade sobre as atividades dos diversos membros dos tribunais de justiça sem prejuízo dos controles internos administrativos e do controle jurisdicional. Entretanto, além da fiscalização, o CNJ tem a missão de integrar programas de informatização, de qualificação de servidores, de acesso à Justiça e de gestão administrativa, em toda a Justiça estadual e federal, atividade antes impossível, devido ao isolamento dos tribunais.

Segundo CNJ (2013), o próprio conselho tem promovido a disseminação de culturas que incentivam a execução de Planejamentos Estratégicos nas diversas instâncias do Poder Judiciário brasileiro, visando, dentre outros aspectos, a promoção de maior transparência e modernização da gestão do Judiciário. Tais temas estão diretamente ligados à agenda da gestão pública contemporânea.

Em meio a essas atribuições, o CNJ tem, também, a tarefa de, em âmbito nacional, lançar 
diretrizes, elaborar instrumentos e operar o sistema de mensuração de desempenho do Poder Judiciário brasileiro. Segundo o art. 14 da Resolução no 76/2009 (CNJ, 2013) este sistema abrange os indicadores estatísticos presentes no relatório Justiça Aberta e na Justiça em Números.

\section{PROCEDIMENTOS METODOLÓGICOS}

A metodologia utilizada neste estudo foi de cunho quantitativo. E segundo aos fins da pesquisa, pode-se definir como descritiva, pois expõe características de determinada população ou de determinado fenômeno, levantando informações sobre situações específicas e relacionadas de forma a proporcionar a visualização de uma totalidade (VERGARA, 2005).

Em relação aos meios, a pesquisa é caracterizada como sendo bibliográfica e documental. Para tanto, os documentos tomados para análise foram: resoluções normativas que lançam diretrizes para o desenvolvimento e operação do sistema de mensuração de desempenho do Judiciário e relatórios/listas de indicadores de desempenho dos sistemas judiciários nacionais e estaduais, sendo, no escopo nacional, um instrumento já em vigor (o relatório Justiça em Números) e outro estadual (relatórios dos sistemas proprietários SAJ e Recursos Humanos).

O universo de pesquisa, coincide com o tamanho da amostra, contemplou 49 (quarenta e nove) varas únicas Tribunal de Justiça do Rio Grandes do Norte, atendendo a ressalva expressa por Ferreira e Gomes (2009). Ou seja, a regra que a técnica DEA deve obedecer, é que o número de unidades (DMUs) deve ser no mínimo duas vezes o número de inputs e outputs considerados. A coleta de dados constitui-se uma etapa importante do estudo, pois contribui para a definição do caminho da pesquisa, traçando em linhas gerais, o modo como é desenvolvida o fenômeno estudado (GIL, 2002)

Em função da natureza escolhida para a pesquisa exploratória, e da necessidade de concentração no tema analisado, foi utilizado os dados secundários oriundos da base de dados dos sistemas do Tribunal de Justiça do RN, Corregedoria Geral de Justiça e do Conselho Nacional de Justiça, compreendendo um período de 03 anos, de 2011 a 2013, conforme figura 1.

Figura 1 - Composição da base de conhecimento da DMU (comarca ou vara do TJRN)

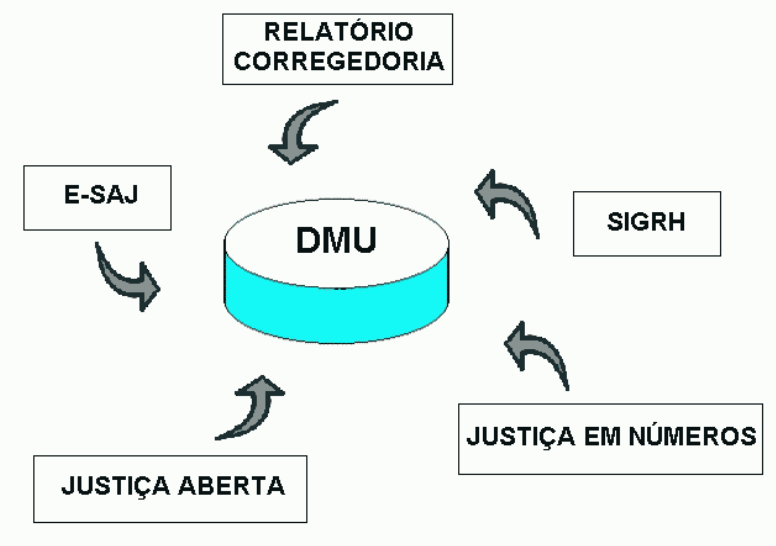

Fonte: Elaborado pelo Autor

Em relação aos procedimentos para execução da pesquisa, pode-se classificar esse trabalho de pesquisa como um Estudo de Caso em um Poder Judiciário, mais especificamente no Tribunal de Justiça do Estado do RN. Após as abordagens teóricas, com o objetivo de aprofundar os mecanismos de mensuração da eficiência pública balizados sob a ótica a Nova Gestão Pública para escolha de um 
modelo matemático de avaliação de eficiência para Poder Judiciário Estadual. O modelo matemático utilizado é composto pelos inputs e outputs distribuídos em seis variáveis. As variáveis são:

(1) Input: (a) processo pendente, essa variável sinaliza o estoque de processos obtida do período anterior o que influencia significativamente o desempenho da agilidade das varas; (b) processos novos, essa variável indica a quantidade de processos obtidos mensalmente pelos fóruns; (c) números de concursados, essa variável indica a quantidade de servidores do TJRN que desempenham atividades nas comarcas ou varas; d) número de servidores cedidos, dependendo do nível e volume de atividades das varas, solicita-se serventuários para atender a demanda dos serviços.

(2) Output: (a) processos sentenciados pertencem como resultado do processo de julgamento das varas como número de sentenças realizadas na vara. Isso significa a produtividade das varas pela quantidade de sentenças julgadas; (b) processos resolvidos, caracteriza a quantidade de trabalhos que foram definitivamente julgados, ou seja, arquivados ou transitados em julgado.

Tal modelo adveio das pesquisas correlacionadas com a temática do presente estudo, conforme quadro a seguir.

Quadro 1 - Estudos correlacionados e variáveis da pesquisa

\begin{tabular}{|c|c|c|c|}
\hline \multirow{7}{*}{ DMU } & & Estudos correlacionados & Variáveis da Pesquisa \\
\hline & \multirow{4}{*}{ INPUT } & $\begin{array}{c}\text { Kuiaski (2001) } \\
\text { Schwengber (2006) }\end{array}$ & ProcPend \\
\hline & & $\begin{array}{l}\text { Nogueira et al (2011) } \\
\text { Souza (2010) }\end{array}$ & ProcNov \\
\hline & & $\begin{array}{l}\text { Nogueira et al (2011) } \\
\text { Souza (2010) } \\
\text { Kuiaski (2001) } \\
\text { Schwengber (2006) }\end{array}$ & NumConc \\
\hline & & $\begin{array}{l}\text { Nogueira et al (2011) } \\
\text { Souza (2010) } \\
\text { Kuiaski (2001) } \\
\text { Schwengber (2006) }\end{array}$ & NumCed \\
\hline & \multirow{2}{*}{ OUTPUT } & $\begin{array}{c}\text { Souza (2010) } \\
\text { Schwengber (2006) }\end{array}$ & ProcResol \\
\hline & & $\begin{array}{l}\text { Nogueira et al (2011) } \\
\text { Kuiaski (2001) }\end{array}$ & ProcSent \\
\hline
\end{tabular}

Fonte: Elaborado pelo Autor

Assim, a eficiência no Poder Judiciário Estadual foi mensurada considerando duas perspectivas: celeridade processual e carga de trabalho e Força de trabalho.

Sob a ótica celeridade processual e carga de trabalho, este estudo observou as variáveis que descrevem a entrada de novos processos judiciais, à carga de trabalho, à taxa de congestionamento processual, à taxa de recorribilidade externa e interna, saída de processos encerrados e/ou resolvidos. E na visão da força de trabalho, este estudo analisou o quantitativo de servidores públicos com capacidade para participar do processo de divisão social do trabalho, no Poder Judiciário Estadual.

A perspectiva da celeridade processual e carga de trabalho foram mensuradas através das:

a. Variáveis inputs : 
- ProcPend (Processos em curso) - Esta variável informou o número de processos pendentes de julgamento, ou seja, total de processos não resolvidos no Órgão Jurisdicional no fim do ano de referência;

- ProcNov (Processos novos) - Esta variável informou o número de novos processos ou processos que foram redistribuídos por outras varas;

b. Variáveis ouput's:

- ProcResol (Processos resolvidos ou arquivados) - Está variável informou o número de processos resolvidos na vara. Entende-se por processos resolvidos, os processos que contém sentenças com mérito ou sentenças sem mérito ou homologação de acordos.

- ProcSent (Número de sentenças realizadas) - Está variável informou o número total de sentenças realizadas no ano de referência.

Sob a perspectiva força de trabalho foi mensurada através das variáveis inputs:

- NumConc (Números de concursados em exercício) - Esta variável revelou se houve excesso ou escassez de servidores efetivos, auxiliares técnicos, técnicos, oficiais de justiça, implicará na eficiência da produção judicial;

- NumCed (Número de cedidos por vara) - Esta variável revelou se excesso ou escassez de servidores efetivos, cedidos, implicará na produção judicial.

Resumidamente, pôde-se descreve a Unidade de Tomadas de Decisão - DMU de uma vara do Tribunal de Justiça do RN, com seus inputs e outputs, conforme figura 2.

Figura 2 - Estrutura de uma unidade de produção - DMU (comarca ou vara do TJRN)

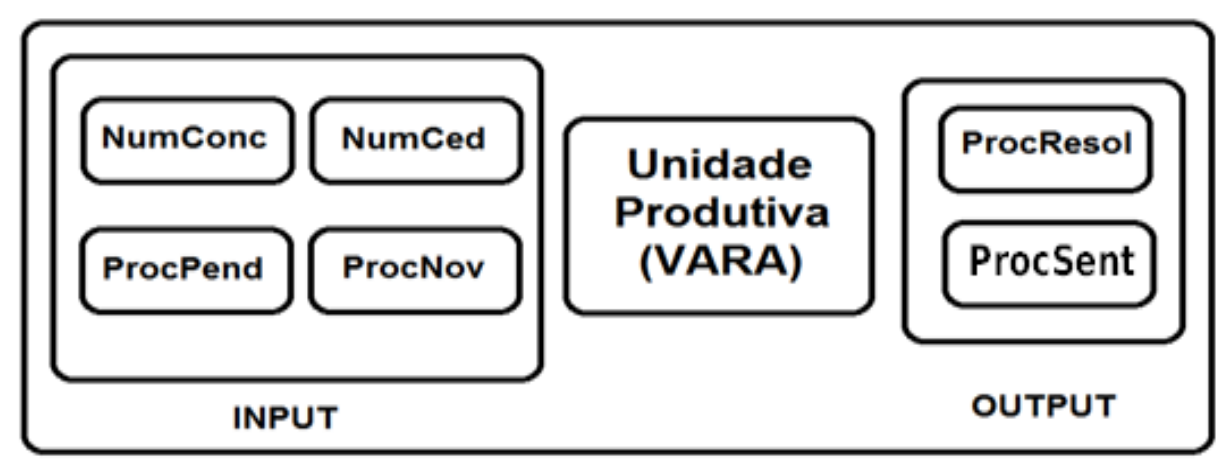

Fonte: Elaborado pelo Autor

O próximo passo foi criar uma base de dados em excel que possibilitou a análise de cada vara ou comarca separadamente, a fim de separar pontos importantes de análise, codificando-os, compilando-os e apresentando-os de forma mais estruturada, segundo o modelo de eficiência adotado. Desta forma, este método permitiu concatenar os dados coletados, estabelecendo informações e conclusões sobre o objeto da análise.

A metodologia, após a base de dados, no formato Excel, foi estruturada por fases, para o período de 2011 a 2013: (1) descrição da estatística básica para identificar alguma distorção nas variáveis em função da média, mediana, desvio padrão, o mínimo e máximo para cada variável; (2) calcular e analisar a correlação entre as variáveis de input e output para cada período (2011, 2012 e 2013). Esse cálculo tem como função identificar o nível de relação entre as variáveis de input e output; (3) Modelo de eficiência compreende o peso (valoração) ideal de cada variável input e output; (4) Ranking de Eficiência - calcular e 
analisar o ranking de eficiência com o uso do modelo CCR orientado para output, para os três períodos 2011, 2012 e 2013. (5) Benchmark - elencar e analisar as DMU's eficientes.

Para efeitos de análise quantitativa aplicou-se a estatística descritiva nas varas únicas do Poder Judiciário Estadual, com propósito de calcular as medidas de tendência central e a dispersão dos dados de cada unidade tomadora de decisão - DMU. Bem como, se fez uso da correlação e em se tratando da análise da eficiência, objetivo principal do estudo, utilizou-se a métrica denominada de Análise Envoltória de Dados (DEA). O modelo DEA foi escolhido para este projeto o Modelo CCR assumindo retornos constantes de escala. A Análise Envoltória de Dados, com ganhos de escala constantes, orientado ao produto é um dos modelos que mais se adéqua a análise de eficiência em Tribunais, pois se trata de insumos e produtos de modo proporcional (escala constante) e orientando o resultado (outputs) em virtude da eficiência da produção dos processos resolvidos e audiências realizadas, mantendo o nível de insumos inalterados.

Em outras palavras, a Análise Envoltória de Dados, avalia a eficiência de unidades organizacionais através de seus insumos (inputs) e produtos (outputs), mensurando os desempenhos das unidades observadas, gerando, assim, uma fronteira de eficiência com base nas melhores avaliações das unidades.

Através do método de Análise Envoltória de Dados, utilizando o software Frontier Analyst, foram identificadas as varas eficientes, na transformação de seus insumos (inputs) em produtos (outputs), bem como as relações entre os insumos e produtos que caracterizam a fronteira de eficiência. Em contrapartida, as ineficiências das demais varas são avaliadas em relação a essa fronteira de produção.

Para fins desse estudo, foi considerado, Unidade de Tomadas de Decisão - DMU como sendo cada unidade jurisdicional das varas únicas das Comarcas de primeira, segunda e terceira entrância, do Tribunal de Justiça do RN.

Entretanto, é necessário interpretar o ranking informado pelo método matemático - DEA. Segundo Lindau et al (2001), benchmarking pode ser definido como um processo contínuo e sistemático utilizado para investigar o resultado (em termos de eficiência e eficácia) das unidades com processos e técnicas comuns de gestão.

Assim, o benchmarking é um parâmetro de comparação entre o desempenho de empresas, processos, produtos, serviços e práticas (CAMP, 1993; SPENDOLINI, 1993). Além disso, de acordo com Camp (1993), o benchmarking identifica os processos, as práticas, os métodos gerenciais para avaliar um ambiente competitivo, sendo assim continuamente monitoradas para garantir a descoberta das melhores práticas exercidas por outras empresas.

Desta forma, a principal função do benchmarking na análise da eficiência é a de auxiliar a tomada de decisões, já que esta ferramenta pode ser utilizada para o estabelecimento de metas que objetivem tornar as unidades ineficientes em eficientes.

Em se tratando da delimitação da pesquisa, a origem deste estudo decorreu da busca no aprofundamento e continuação dos estudos transversais entre os temas: Administração Pública, Nova Gestão Pública, Microeconomia, Eficiência e Poder Judiciário, ou seja, particularmente, buscou-se analisar a eficiência relativa do Tribunal de Justiça do RN.

Entretanto, devido às limitações no uso da ferramenta DEA, Lins e Ângulo-Meza (2000) afirmam que as DMU's deverão possuir as mesmas características. Portanto, a presente pesquisa foi realizada apenas nas varas únicas, das Comarcas de primeira, segunda e terceira entrância do Poder Judiciário do RN. 


\section{ANÁLISE E DISCUSSÃO DOS RESULTADOS}

$\mathrm{Na}$ distribuição dos dados, observou-se, então, uma diferença significativa entre o máximo e mínimo das variáveis inputs e outputs informando que as varas únicas do Poder Judiciário Estadual do RN possuem uma grande diversidade numérica nas duas óticas: força de trabalho e carga de trabalho (volume processual). No ano de 2011, existiram varas únicas onde o volume de processos novos somando ao processo pendente é de quase igual a 07 (sete) mil processos ativos, e na menor vara não chega a 400 processos. No ano de 2012, existiram varas únicas onde o volume de processos novos somando ao processo pendente é de quase igual a 07 (sete) mil processos ativos, e na menor vara não chega a 400 processos, conforme tabela 2. Em 2013, o volume de processos novos com os processos pendentes quase ultrapassa a marca de 08 (oito) mil processos, e na menor vara, também, não chegou a atingir 450 processos.

Buscando-se adotar instrumentos de gestão que visam à medição do desempenho, bem como do incremento de sua eficiência e resultados (ARAÚJO E BESSA,2010). Foi utilizado o software Frontier Analyst para implementação do modelo e cálculo da fronteira de eficiência através do método DEA.

A Tabela 1 apresentou a distribuição de eficiência dos fóruns das varas únicas com todas as variáveis do modelo no período entre 2011 a 2013. Destaca-se Garbardo (2002) que eficiência pode ser quantificada através da relação entre os insumos (inputs) e produtos (outputs). De maneira global, o modelo CCR orientando ao output contemplou seis fóruns eficientes que se manteve nos três períodos.

Tabela 1 - Taxa de eficiência das varas únicas dos fóruns do RN

(Continua)

$\begin{array}{ccccr}\text { DMU - Varas } & 2011 & 2012 & \begin{array}{c}201 \\ 3\end{array} & \begin{array}{c}\text { Eficiência } \\ \text { Média }\end{array} \\ \text { Angicos } & 100 & 100 & 100 & 100 \\ \text { Florânia } & 100 & 100 & 100 & 100 \\ \text { Jardim do Seridó } & 100 & 100 & 100 & 100 \\ \text { Luís Gomes } & 100 & 100 & 100 & 100 \\ \text { Pendências } & 100 & 100 & 100 & 100 \\ \text { São João do Sabugi } & 100 & 100 & 100 & 100 \\ \text { Cruzeta } & 100 & 100 & 80,7 & 93,57 \\ & & & 1 & \\ \text { Upanema } & 100 & 85,45 & 66,0 & 83,84 \\ \text { Taipu } & 100 & 84,52 & 53,1 & 79,23 \\ & & & 7 & \\ \text { São Paulo do } & 100 & 82,81 & 96,6 & 93,16 \\ \text { Potengi } & & & 7 & 83,03 \\ \text { São Bento do Norte } & 100 & 79,97 & 69,1 & 81,56 \\ \text { Baraúna } & 100 & 69,57 & 75,1 & 65,07 \\ \text { Umarizal } & 100 & 69,1 & 65,1 & \end{array}$

Nucleus,v.12,n.2,out.2015 
Tabela 1 - Taxa de eficiência das varas únicas dos fóruns do RN

(Continua)

\begin{tabular}{|c|c|c|c|c|}
\hline DMU - Varas & 2011 & 2012 & $\begin{array}{c}201 \\
3\end{array}$ & $\begin{array}{l}\text { Eficiência } \\
\text { Média }\end{array}$ \\
\hline Extremoz & 100 & 61 & 100 & 87 \\
\hline Serra Negra do & 99,3 & 100 & 99,0 & 99,47 \\
\hline Norte & 3 & & 9 & \\
\hline Pedro Avelino & $\begin{array}{c}98,6 \\
9\end{array}$ & 58,08 & $\begin{array}{c}71,5 \\
5\end{array}$ & 76,11 \\
\hline Lajes & $\begin{array}{c}97,6 \\
6\end{array}$ & 62,52 & $\begin{array}{c}63,4 \\
1\end{array}$ & 74,53 \\
\hline Portalegre & 94,2 & 74,09 & $\begin{array}{c}80,4 \\
2\end{array}$ & 82,9 \\
\hline Pedro Velho & $\begin{array}{c}92,8 \\
5\end{array}$ & 96,7 & $\begin{array}{c}81,5 \\
8\end{array}$ & 90,38 \\
\hline Arez & $\begin{array}{c}90,4 \\
5\end{array}$ & 100 & $\begin{array}{c}87,0 \\
4\end{array}$ & 92,5 \\
\hline Campo Grande & $\begin{array}{c}89,9 \\
7\end{array}$ & 76,58 & $\begin{array}{c}70,0 \\
7\end{array}$ & 78,87 \\
\hline Caraúbas & $\begin{array}{c}89,2 \\
1\end{array}$ & 82,55 & 98 & 89,92 \\
\hline Jucurutu & $\begin{array}{c}88,5 \\
8\end{array}$ & 84,3 & $\begin{array}{c}72,8 \\
6\end{array}$ & 81,91 \\
\hline $\begin{array}{l}\text { Gov. Dix - Sept } \\
\text { Rosado }\end{array}$ & $\begin{array}{c}88,2 \\
6\end{array}$ & 82,56 & $\begin{array}{c}67,8 \\
6\end{array}$ & 79,56 \\
\hline Nísia Floresta & $\begin{array}{c}87,2 \\
1\end{array}$ & 73,56 & 100 & 86,92 \\
\hline Acari & 82,3 & 76,37 & $\begin{array}{c}76,2 \\
6\end{array}$ & 78,31 \\
\hline Jardim de Piranhas & $\begin{array}{c}81,6 \\
1\end{array}$ & 65,67 & $\begin{array}{c}84,8 \\
4\end{array}$ & 77,37 \\
\hline Martins & $\begin{array}{c}81,5 \\
8\end{array}$ & 41,45 & $\begin{array}{c}73,3 \\
6\end{array}$ & 65,46 \\
\hline Touros & $\begin{array}{c}80,2 \\
5\end{array}$ & 51,12 & $\begin{array}{c}91,1 \\
2\end{array}$ & 74,16 \\
\hline Janduís & $\begin{array}{c}79,9 \\
4\end{array}$ & 95,31 & $\begin{array}{c}93,3 \\
9\end{array}$ & 89,55 \\
\hline São Rafael & $\begin{array}{c}79,8 \\
1\end{array}$ & 49,75 & $\begin{array}{c}53,9 \\
8\end{array}$ & 61,18 \\
\hline São Miguel & $\begin{array}{c}79,0 \\
6\end{array}$ & 74,13 & 100 & 84,4 \\
\hline Marcelino Vieira & $\begin{array}{c}76,8 \\
4\end{array}$ & 87,56 & $\begin{array}{c}98,1 \\
6\end{array}$ & 87,52 \\
\hline
\end{tabular}


Tabela 1 - Taxa de eficiência das varas únicas dos fóruns do RN

\begin{tabular}{|c|c|c|c|c|}
\hline DMU - Varas & 2011 & 2012 & $\begin{array}{c}201 \\
3\end{array}$ & $\begin{array}{l}\text { Eficiência } \\
\text { Média }\end{array}$ \\
\hline atu & $\begin{array}{c}76,7 \\
3\end{array}$ & 100 & 100 & 92,24 \\
\hline Goianinha & $\begin{array}{c}76,4 \\
5\end{array}$ & 68,14 & $\begin{array}{c}69,2 \\
9\end{array}$ & 71,29 \\
\hline Poço Branco & $\begin{array}{c}75,2 \\
6\end{array}$ & 100 & $\begin{array}{c}71,1 \\
3\end{array}$ & 82,13 \\
\hline Monte Alegre & 74,7 & 95,88 & $\begin{array}{c}68,2 \\
4\end{array}$ & 79,61 \\
\hline Tangará & $\begin{array}{c}74,1 \\
1\end{array}$ & 60,97 & $\begin{array}{c}45,9 \\
5\end{array}$ & 60,34 \\
\hline Alexandria & $\begin{array}{c}73,5 \\
7\end{array}$ & 58,44 & 100 & 77,34 \\
\hline Santana do Matos & $\begin{array}{c}65,6 \\
1\end{array}$ & 100 & 100 & 88,54 \\
\hline Almino Afonso & 65,6 & 91,96 & $\begin{array}{c}88,0 \\
1\end{array}$ & 81,86 \\
\hline Ipanguaçu & $\begin{array}{c}65,5 \\
4\end{array}$ & 63,2 & 93 & 73,91 \\
\hline São José do Mipibu & 64,6 & 61,59 & $\begin{array}{c}45,6 \\
9\end{array}$ & 57,29 \\
\hline Afonso Bezerra & $\begin{array}{c}62,0 \\
7\end{array}$ & 76,35 & $\begin{array}{c}83,0 \\
3\end{array}$ & 73,82 \\
\hline $\begin{array}{l}\text { São José do } \\
\text { Campestre }\end{array}$ & $\begin{array}{c}58,7 \\
6\end{array}$ & 73,73 & $\begin{array}{c}59,8 \\
7\end{array}$ & 64,12 \\
\hline Parelhas & $\begin{array}{c}56,0 \\
1\end{array}$ & 69,91 & 100 & 75,31 \\
\hline Santo Antônio & $\begin{array}{c}53,8 \\
7\end{array}$ & 61,68 & $\begin{array}{c}49,2 \\
4\end{array}$ & 54,93 \\
\hline São Tomé & $\begin{array}{c}52,6 \\
6\end{array}$ & 58,55 & $\begin{array}{c}52,9 \\
1\end{array}$ & 54,71 \\
\hline Canguaretama & $\begin{array}{c}42,3 \\
7\end{array}$ & 54,81 & $\begin{array}{c}85,2 \\
1\end{array}$ & 60,8 \\
\hline Total (média) & $\begin{array}{c}83,5 \\
8\end{array}$ & 78,77 & $\begin{array}{c}81,2 \\
3\end{array}$ & 81,19 \\
\hline Mínimo & $\begin{array}{c}42,3 \\
7\end{array}$ & 41,45 & $\begin{array}{c}45,6 \\
9\end{array}$ & 41,45 \\
\hline DP & $\begin{array}{c}13,3 \\
37\end{array}$ & $\begin{array}{c}14,65 \\
2\end{array}$ & $\begin{array}{c}14,9 \\
8\end{array}$ & 9,847 \\
\hline Mediana & $\begin{array}{c}87,2 \\
1 \\
\end{array}$ & 76,58 & $\begin{array}{c}83,0 \\
3\end{array}$ & 81,86 \\
\hline
\end{tabular}


Ainda, de acordo com a tabela 01, percebeu-se que o período de 2011, presenciou 14 varas eficientes constatando uma eficiência média de 83,58\%. No período 2012, encontrou-se 12 varas eficientes, embora a eficiência média dessas varas tivesse um decréscimo na sua taxa $(78,77 \%)$. Já o período de 2013, teve-se 13 varas eficientes onde a taxa de eficiência recuperou em relação a 2011, porém ainda apresente ineficiência no seu conjunto $(81,23 \%)$. Logo, constatou-se que apesar da eficiência média ter sido menor, houve também um desvio padrão maior, o que avalia constar uma maior variabilidade dos dados.

Como esperado para este curto período de tempo, a eficiência média não se alterou significativamente. Nos três anos, os Tribunais Estaduais tiveram desempenho de cerca de 81,19. No entanto, Kuiaski (2001) resalta que o DEA fornece medidas de eficiência relativa, ou seja, todas as unidades estão sendo comparadas com as unidades mais eficientes, que se encontram na fronteira. $\mathrm{O}$ que estes números querem dizer é que a distância das unidades ineficientes à fronteira não se alterou de forma significativa nos três anos. Não é automático inferir que a fronteira não se alterou neste mesmo período de tempo, apesar de que podemos desconfiar que a mudança - se de fato ocorreu - tenha sido pequena.

Em relação à força de trabalho, observou-se que as varas únicas que obtiverem eficiências de $100 \%$ são as varas que possuem o número de servidores efetivos maior que o número de servidores cedidos. Ou seja, no triênio, as varas que tem mais servidores concursados possuem um percentual de 71, $42 \%$, no ano de $2011,75,00 \%$, no ano de 2012 e 69,23\%, no ano de 2013, de varas eficientes, conforme tabela a seguir.

Tabela 2 - Taxa de eficiência - relação força de trabalho versus eficiência

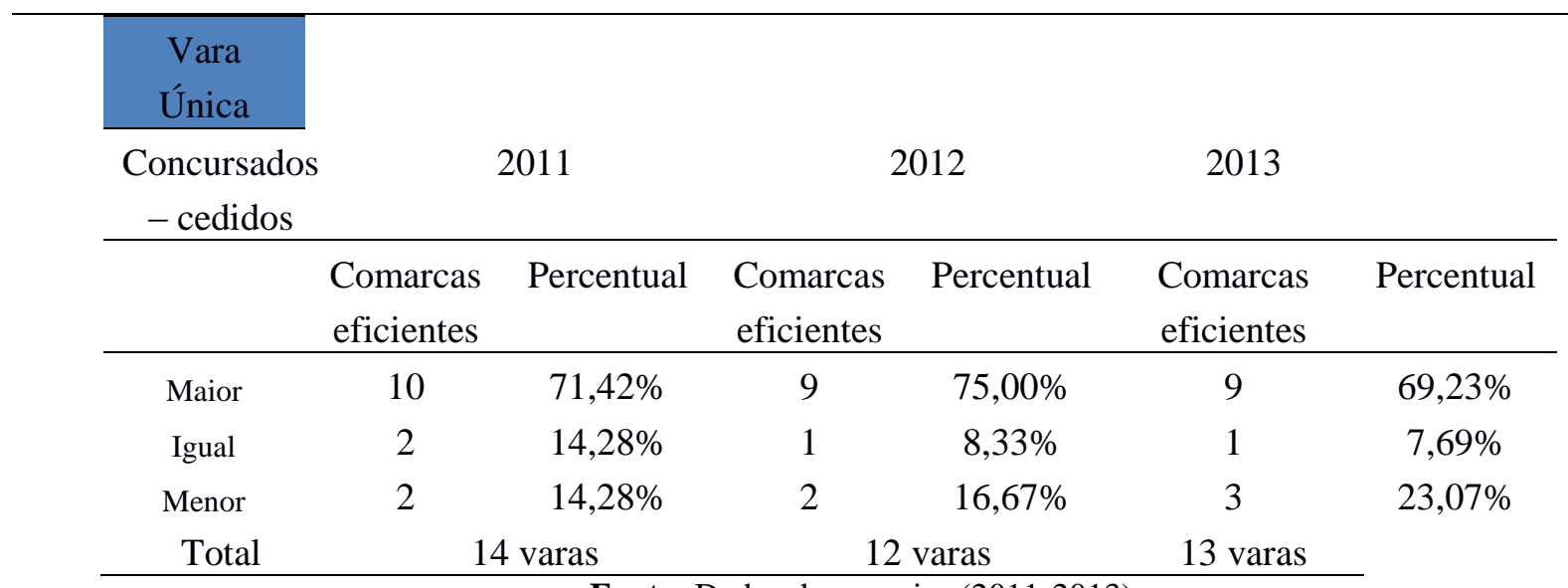

Fonte: Dados da pesquisa (2011-2013)

Considerou-se como volume processual da vara única, a quantidade de processos inseridos na vara (processos novos) mais a quantidade de processos que não foram resolvidos ou julgados (processos pendentes), no ano anterior subtraindo da quantidade de processos que foram resolvidos, no corrente ano. Entretanto, demonstrou que as varas com eficiência de $100 \%$ foram as varas que possuem o menor volume processual, independe, se a vara produziu muitos processos realizados ou sentenciados. Desta forma, percebeu-se que as varas únicas eficientes estão fortemente relacionadas com a dimensão da unidade jurisdicional. A tabela a seguir, corrobora com a análise, demonstrou-se que para o ano de 2011, tem-se $78,57 \%$, no ano de 2012 , tem-se $91,67 \%$ e no ano de 2013 , tem-se $46,15 \%$, de varas eficientes, como volume processual de 107 a 1649 processos. 
Tabela 3 - Taxa de eficiência - relação volume processual versus eficiência

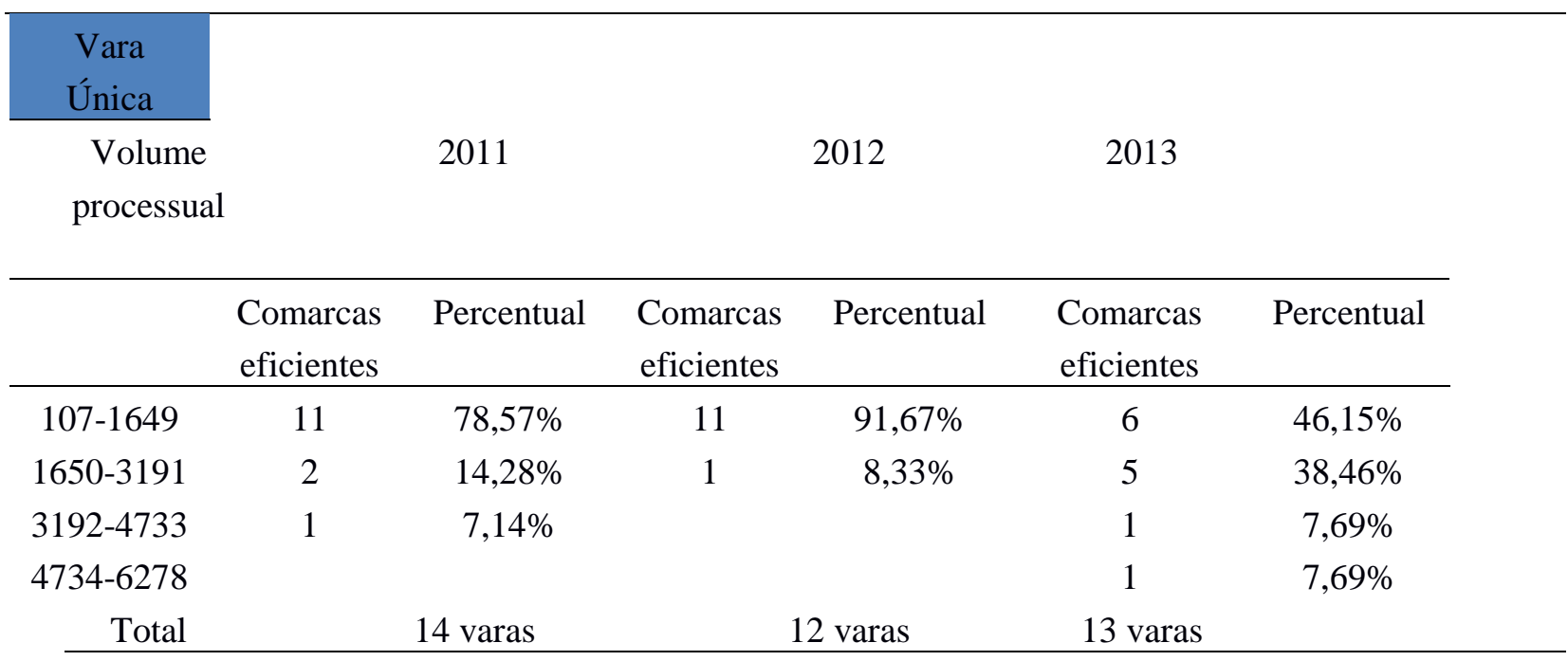

Fonte: Dados da pesquisa (2011-2013)

E, reafirmando os estudos de Souza (2010) e Schwengber (2006), constatou-se, durante todo triênio, que as varas ou comarcas com níveis de eficiência de $100 \%$ contam proporcionalmente com menos servidores, conforme tabela a seguir.

Tabela 4 - Taxa de eficiência - relação quantitativo pessoal versus eficiência

\begin{tabular}{|c|c|c|c|c|c|c|}
\hline $\begin{array}{l}\text { Vara } \\
\text { Única }\end{array}$ & & & & & & \\
\hline Quantidade & \multicolumn{2}{|c|}{2011} & \multicolumn{2}{|c|}{2012} & \multicolumn{2}{|l|}{2013} \\
\hline $\mathrm{S}$ & $\begin{array}{l}\text { Comarcas } \\
\text { eficientes }\end{array}$ & $\begin{array}{c}\text { Percentua } \\
\text { l }\end{array}$ & $\begin{array}{l}\text { Comarcas } \\
\text { eficientes }\end{array}$ & Percentual & $\begin{array}{l}\text { Comarcas } \\
\text { eficientes }\end{array}$ & $\begin{array}{c}\text { Percentua } \\
\text { l }\end{array}$ \\
\hline 01-07 & 10 & $71,43 \%$ & 10 & $83,33 \%$ & 9 & $75,00 \%$ \\
\hline $08-15$ & 4 & $28,57 \%$ & 2 & $16,67 \%$ & 4 & $33,33 \%$ \\
\hline $16-21$ & 0 & $0,00 \%$ & 0 & $0,00 \%$ & 0 & $0,00 \%$ \\
\hline Total & \multicolumn{2}{|c|}{14 varas } & \multicolumn{2}{|c|}{12 varas } & 13 varas & \\
\hline
\end{tabular}

Fonte: Dados da pesquisa (2011-2013)

Segundo Fochezatto (2010), a análise de eficiência tem o objetivo de construir um ou um conjunto de benchmark (ou fronteira de produção) que permita a comparação entre unidades para classificá-las segundo o critério adotado, neste caso, CCR voltado a output. A medida de eficiência é relativa. Não possibilitando comparações absolutas, ou seja, as unidades são ditas eficientes sempre em relação ao grupo observado com o qual elas estão sendo comparadas.

Dessa forma, as varas únicas, aquelas tidas como obtiveram níveis de eficiência de $100 \%$, servindo-se de referência para as demais varas únicas. Assim, em 2011, teve-se 14 varas como referência (benchmark), por exemplo, a vara única de Baraúnas. Em 2012, teve-se 12 varas como referência (benchmark), por exemplo, a vara única de Arês. E em 2013, teve-se 13 varas como referência (benchmark), por exemplo, a vara única de Pendências, conforme tabela 11. 
Tabela 5 - Benchmark das varas únicas

\begin{tabular}{lll}
\multicolumn{1}{c}{ BENCHMARK } & \multicolumn{1}{c}{2012} & \multicolumn{2}{c}{2013} \\
\hline Angicos & & \\
Baraúnas & Angicos & Angicos \\
Cruzeta & Arês & Alexandria \\
Extremoz & Cruzeta & Extremoz \\
Florânia & Florânia & Florânia \\
Jardim do Sérido & Jardim do Sérido & Jardim do Sérido \\
Luís Gomes & Luís Gomes & Luís Gomes \\
Pendências & Patu & Nísia Floresta \\
São Bento do Norte & Pendências & Parelhas \\
São João do Sabugi & Poço Branco & Patu \\
São Paulo do Potengi & Santana do Matos & Pendências \\
Taipu & São João do Sabugi & Santana do Matos \\
Umarizal & Serra Negra do Norte & São João do Sabugi \\
Upanema & & São Miguel \\
\hline
\end{tabular}

Fonte: Dados da pesquisa (2011-2013)

Com base nos dados utilizados, foram computados os níveis de eficiência para o triênio 20112013, para melhor compreensão, dividiu em três grupos: a) aqueles que alcançaram níveis mais elevados, b) os que decaíram e c) os que mantiveram eficientes, conforme desempenho estimado. Revelam, assim, a seguinte distribuição, conforme tabela 12 a seguir.

Tabela 6 - Perfil da eficiência nas varas únicas

\begin{tabular}{lcc}
\multicolumn{1}{c}{ Perfil } & Varas Únicas & Porcentagem \\
\hline Com perda de eficiência & 11 & $22,45 \%$ \\
Com eficiência inalterada & 06 & $12,24 \%$ \\
Com crescimento de eficiência & 06 & $12,24 \%$ \\
Com alternância de eficiência & 26 & $53,06 \%$ \\
Total & 49 & $100,00 \%$ \\
\hline
\end{tabular}

Fonte: Dados da pesquisa (2011-2013)

Somando o número de varas que mantiveram o nível de eficiência junto à fronteira com aqueles que obtiveram ganhos de eficiência, verifica-se que apenas 12 , ou seja, $24,48 \%$, dos atuais 49 , apresentam trajetória eficiente.

Ainda, do exposto ao longo da pesquisa, no escopo vara única, o que se constatou foi que as estruturas das unidades judiciais únicas, a variável output - processos resolvidos são mais influenciados pelo variável input - processos novos e a variável output - processos sentenciados são mais influenciados pelo variável input - processos pendentes. 
Desta forma, a técnica apresentada permitiu identificar o comportamento de determinados fatores inerentes à prestação jurisdicional, possibilitando um enriquecimento na gestão de recursos, tornando-a mais científica, ágil e confiável (NOGUEIRA ET AL, 2011).

Corroborando-se com Souza (2010), os resultados obtidos apontaram, de modo geral, que o Poder Judiciário Estadual necessita melhorar seu desempenho junto à fronteira, dado o caráter irregular de crescimento e as perdas apresentadas por algumas varas ou comarcas.

\section{CONSIDERAÇÕES FINAIS}

As diversas reformas administrativas do Estado tiveram significativa influência na reforma do Poder Judiciário, haja vista que a partir da reforma administrativa de 1937, ocorreu a transição da administração patrimonialista de Estado para a administração burocrática, em seguida, com a Constituição Federal de 1988 houve a tentativa de inserção do modelo de administração pública gerencial em substituição do modelo burocrático.

Com o Plano Diretor de Reforma do Aparelho do Estado (PDRAE),em 1995, buscou-se o desenvolvimento da cultura gerencial nas organizações públicas, estando aí inserida a reforma do Poder Judiciário, a qual veio a ser realizada, por meio, da Emenda Constitucional n 45/2004.

Com a edição da Emenda Constitucional no 19 de 04 de junho de 1998 e a inserção do princípio da eficiência no artigo 37, da Constituição Federal, bem com a edição da Resolução no 70/2009, do CNJ observa-se que o desempenho do Poder Judiciário na prestação jurisdicional ágil, acessível, eficaz e eficiente passou a ser aperfeiçoada por meio de gestão e planejamento estratégico.

Nesse panorama, o tema da Gestão do Poder Judiciário e, por conseguinte, o da mensuração da sua eficiência, tem criado no judiciário nacional e estadual, movimento de disseminação da cultura e prática da mensuração e do planejamento estratégico que enfrente os problemas estruturais e organizacionais. Este contexto tem levado à identificação de necessidades de nivelamentos estruturais que visam o estabelecimento de padrões administrativos mínimos a serem seguidos pelas organizações para a adoção de uma mensuração e um planejamento efetivo, iniciado em âmbito estadual e refletido nacionalmente (e vice-versa).

Nesta perspectiva, o presente estudo investigou a eficiência judicial visando reconhecer o nível de eficiência das varas únicas do Poder Judiciário Estadual. Esse tipo de pesquisa permitiu identificar quais unidades jurisdicionais devem ser imitadas e quais devem buscar melhorias em seus processos produtivos, sentenças e resolvidos. A comparação entre unidades teve como base o conceito de eficiência, mais especificamente, a noção de eficiência técnica.

Os critérios de comparação utilizados envolveram diferentes conjuntos de insumos e produtos, sob dois aspectos: celeridade processual, carga de trabalho e força de trabalho. Os insumos utilizados foram: processos pendentes, processos novos, número de cedidos e número de efetivos; e os produtos utilizados foram: processos sentenciados e resolvidos. As análises foram focadas ou direcionadas em função dos produtos com o objetivo de estimar o quanto poderia ser produzido com os mesmos insumos, ou seja, em quanto o Tribunal de Justiça do RN pode maximizar a produção de processos sentenciado e resolvidos com a mesma disposição da carga e força de trabalho.

Os recursos humanos, servidores cedidos e efetivos, foram analisados neste estudo. As evidências a respeito da importância de recursos humanos para a eficiência do Tribunal de Justiça do RN, com vistas para produção de processos sentenciados e resolvidos, foi observada que parcela significativa da variação

Nucleus,v.12,n.2,out.2015 
do desempenho do Poder Judiciário Estadual pode ser explicada pela disponibilidade da força de trabalho dos servidores efetivo em contrapartida dos servidores cedidos.

A principal constatação é que a força de trabalho, servidores efetivos, influencia positivamente a eficiência das varas únicas sob o aspecto na produção de processos sentenciados e resolvidos. Entretanto, a força de trabalho, servidores cedidos, influencia negativamente a eficiência das varas analisadas.

Outra evidência no estudo é no aspecto volume processual (processos novos, pendentes). Verificou-se, de maneira geral, que comarcas ou varas que possuem o menor volume processual tendem a ser mais eficientes. Essa relação retrata mais a realidade, pois é mais fácil gerenciar os recursos em uma vara e/ou comarca de menor complexidade processual do que uma com complexidade processual mais intensa.

Os resultados obtidos apontaram, de modo geral, que Poder Judiciário Estadual necessita melhorar seu desempenho junto à fronteira da eficiência, dado o caráter irregular de crescimento e as perdas apresentadas por algumas comarcas e/ou varas. Ou seja, a alternância da eficiência nas varas únicas, no decorrer dos anos de 2011 a 2013, apontaram como obstáculos à melhoria do desempenho judicial do Estado do RN devido à falta de padronização e o excesso de formalismo em procedimentos legais e administrativos.

Assim, evidencia que a presença de uma gestão eficiente à luz do conhecimento das variáveis, input e output, das unidades jurisdicionais analisadas pode contribuir para aperfeiçoar o desempenho nas resoluções dos litígios judiciais.

Como as leis processuais são as mesmas em todas as unidades jurisdicionais no estado do Rio Grande do Norte, é razoável supor que existe pouca flexibilidade para se definir a forma de atuação em termos processuais e em termos de interpretação da lei nas decisões. As grandes diferenças no desempenho da eficiência advêm das diferentes formas com que as varas e comarcas se organizam internamente e decidem pela alocação dos recursos disponíveis.

Dentre as limitações desta pesquisa pode-se ressaltar a natureza determinística da modelagem DEA ou mesmo a ausência de outras variáveis no modelo poderia viesar a análise. O cuidado no processo de seleção foi dar lugar àquelas variáveis diretamente envolvidas na determinação da mensuração da eficiência e as análises e sugestões, decorrentes desta metodologia, estão condicionadas às unidades e variáveis incluídas neste estudo. Qualquer unidade e/ou variável acrescentada ou excluída da análise modificarão os resultados.

Entretanto, o modelo DEA não consegue capturar ou mensurar em toda sua extensão uma característica peculiar da Administração Pública, variáveis contextuais no desempenho individual dos servidores públicos.

E devido às limitações no uso da ferramenta DEA, Lins e Ângulo-Meza (2000) afirmam que as DMU’s deverão possuir as mesmas características. Portanto, a presente pesquisa realizou apenas nas varas únicas. Como sugestões de pesquisas futuras, à influência da força de trabalho na eficiência ainda precisa ser investigada e estudada. É necessário compreender porque, de fato, os servidores efetivos se sobressaem sobre os cedidos, na produção dos processos, sentenciados e resolvidos, ou seja, poderia ser observado o grau de estudos desses servidores, a idade, grau de satisfação, tempo de serviço na área pública.

Ainda sob a ótica força de trabalho, é importante ressaltar o trabalho dos magistrados, pois nesse estudo, o juiz foi considerado como um servidor concursado com o mesmo valor de um servidor que trabalha apenas na secretaria judiciária. Entretanto, o magistrado é um fator determinante da produtividade 
e celeridade nos processos judiciais. Por isso, deve considerar as particularidades dessa possível variável, como por exemplo: tempo de serviço, idade, grau de conhecimento, dentre outras opções.

E com advento do processo judicial eletrônico e o procedimento operacional padrão no âmbito do Poder Judiciário Estadual. Pesquisas futuras poderiam investigar se adesões dessas duas ferramentas influenciarão de maneira positiva na eficiência judicial do Tribunal de Justiça do RN.

A mensuração de eficiência do Poder Judiciário Estadual foi tratada sob uma análise quantitativa. Por isso, como estudos futuros, deveria considerar uma pesquisa que incorporasse variáveis individuais, relacionais e contextuais, ou seja, realizar uma pesquisa qualitativa e quantitativa. Dessa forma, o efeito ou influência de uma determinada característica de uma variável na eficiência poderia ser atenuado ou reforçado, por exemplo, por características relacionais, como o desempenho de pares, e por características contextuais, como condições de trabalho em comarcas, estratégias gerenciais utilizadas nas varas e características dos servidores e assim, gerar informações aos gestores públicos, sob uma ótica, também, qualitativa.

\section{REFERÊNCIAS}

ABRÚCIO, F.L.. A trajetória recente da gestão pública brasileira: um balanço crítico e a renovação da agenda de reformas. Revista de Administração Pública, Rio de Janeiro, vol. 41, n. especial, p. 67-86, 2007.

ARAUJO, I.V.; BESSA, L.F.M.. Eficiência e Efetividade no Poder Judiciário: O Estado da Arte e Proposições de Pesquisas. Anais do Encontro de Administração Pública e Governança, ANPAD, Vitória, 2010.

ALEXANDRINO, M.. Direito administrativo descomplicado - 20. ed. ver. e atual - Rio de Janeiro: Forense; São Paulo: MÉTODO, 2012.

(BRASIL, 1967). Decreto-Lei n ${ }^{\circ}$ 200, de 25 de fevereiro de 1967. Dispõe sobre a organização da Administração Federal, estabelece diretrizes para a Reforma Administrativa e dá outras providências. Legislação Federal. sítio eletrônico internet - planalto.gov.br. Acesso em: 03 abril. 2014.

(BRASIL, 1988). Constituição da República Federativa do Brasil. Legislação Federal. sítio eletrônico internet - planalto.gov.br. Acesso em: 03 abril. 2014.

(BRASIL,1988). Emenda Constitucional no 19 de 04/06/98. Legislação Federal. sítio eletrônico internet - planalto.gov.br. Acesso em: 03 abril. 2014.

(BRASIL,2000). Lei Complementar 101, de 04 de maio de 2000. Legislação Federal. sítio eletrônico internet - planalto.gov.br. Acesso em: 03 abril. 2014.

(BRASIL,2004). Emenda Constitucional de no 45, de 2004 . Legislação Federal. sítio eletrônico internetplanalto.gov.br. Acesso em: 03 abril. 2014.

(BRASIL,2004). Lei n. 12.527/2011 - Lei de Acesso à Informação. Legislação Federal. sítio eletrônico internet - cnj.jus.br. Acesso em: 17 maio. 2014.

(BRASIL,2005). Decreto $\mathrm{n}^{\mathrm{o}}$ 5.378, de 23 de fevereiro de 2005. Institui o Programa Nacional de Gestão Pública e Desburocratização - GESPÚBLICA e o Comitê Gestor do Programa Nacional de Gestão Pública e Desburocratização, e dá outras providências. Brasília -DF. 
BRESSER-PEREIRA, L.C.. Da administração Pública Burocrática à Gerencial. Revista do Serviço Público, 47(1) janeiro-abril. 1996.

Da administração pública burocrática à gerencial. In PEREIRA, Luiz Carlos Bresser, e SPINK, Peter (org). Reforma do Estado e administração pública gerencial, $3^{\mathrm{a}}$ ed. Rio de Janeiro: FGV, p 237 a 270. 1999.

O modelo estrutural de gerência pública. Revista de Administração Pública (RAP) - Rio de Janeiro 42(2):391-410, Mar./abr. 2008

BRULON, V.. Administração Pública para o Desenvolvimento: Superando a Primazia da Eficiência para o Alcance de um Desenvolvimento Multidimensional. Anais do Encontro de Administração Pública e Governo. ANPAD, Salvador, 2012.

CASTRO, R..B.de. Eficácia, Eficiência e Efetividade na Administração Pública. Anais do $\mathbf{3 0}^{\mathbf{0}}$ Encontro da ANPAD, Salvador,2006.

CAMP, R.. Benchmarking: identificando, analisando e adaptando as melhores práticas da administração que levam à maximização da performance empresarial. São Paulo: Pioneira, 1993.

(CNJ,2009). Art. 14 da Resolução no 76/2009. CNJ. sítio eletrônico internet - cnj.jus.br. Acesso em: 17 maio. 2014.

(CNJ, 2012). Portaria n. 216, de 19 de dezembro de 2012. Legislação Federal. sítio eletrônico internet cnj.jus.br . Acesso em: 17 maio. 2014.

FERREIRA, C.M.de C.; GOMES, A. P.. Introdução à Análise Envoltória de Dados. Viçosa: Editora UFV, 2009.

FOCHEZATTO, A. Análise da eficiência relativa dos tribunais da justiça estadual brasileira utilizando o método DEA. Anales Reunión de Estudios Regionales, 36. 2010, Badajoz: AECR, 2010.

GIL, A.C. M.. Como elaborar projetos de pesquisa. 4. ed. São Paulo: Atlas, 2002.

HESS, H. C.. O princípio da Eficiência e o Poder Judiciário. Revista Fac. Dir. Univ. SP, v.105, p. 211239, jan-dez, 2010.

KUIASKI, L. T. R. Avaliação Organizativa - Uma Abordagem Não-paramétrica junto ao Tribunal Regional do Trabalho da 9a. Região. Universidade do Rio Grande do Sul, UFRGS, 2001.

LINDAU, L.A.; COSTA,M.B.B.; SOUSA, F.B.B. Em busca do benckmark da produtividade de operadores urbanos de ônibus. In: Transportes: experiências em rede. p. 199-221, 2001.

LINS, M. P. E.; ANGULO-MEZA, L. Análise Envoltória de Dados e perspectivas de integração no ambiente de Apoio à Decisão. Rio de Janeiro: Editora da COPPE/UFRJ, 2000.

MODESTO, P.. Notas para um debate sobre o princípio da eficiência. Revista do Serviço Público, Brasília, ano 51, n.2, p. 105 - 120, Abr-Jun, 2000.

NOGUEIRA, J. M. M.et al.Estudo exploratório da eficiência dos tribunais de justiça estaduais através da Análise Envoltória de Dados (DEA). Anais do Encontro da Associação Nacional de Pós-Graduação e Pesquisa em Administração, 35, 2011, Rio de Janeiro: ANPAD, 2011.

NUNES, E.. A gramática política do Brasil: clientelismo e insulamento burocrático. Rio de Janeiro: Jorge Zahar; Brasília: ENAP, 1997. 139p. 
PAES, J.E.S.. O Novo Direito Administrativo Brasileiro. Belo Horizonte: Fórum, 2003, p.275-286.

RENAULT, S.R.T.. A Reforma do Poder Judiciário sob a ótica do governo federal. Revista do Serviço Público Brasília, 56 (2): 127-136 Abr/Jun 2005.

REZENDE, F.da C.. Por Que Falham as Reformas Administrativas? Rio de Janeiro: Editora FGV, 2004.132p.

SCHWENGBER, S.B.. Mensurando a Eficiência no Sistema Judiciário: Métodos Paramétricos e Não-Paramétricos - Dissertação de Doutorado em Economia do Setor Público, Universidade de Brasília - UnB. 2006.

SANO, H.. Nova Gestão Pública e accountability: o caso das organizações sociais paulistas. São Paulo: FGV/EAESP, 2003, 149 p.

SENA, G.A.. Reforma do Poder Judiciário no Brasil: uma análise a partir das metas do Conselho Nacional de Justiça. Anais do $36^{\circ}$ Encontro da ANPAD, Rio de Janeiro, 2012.

SOUZA, A. P. Mensuração da Eficiência na Justiça do Trabalho: Uma Análise Não-paramétrica. Dissertação de Mestrado em Economia do Setor Público, Universidade de Brasília - UnB. 2010.

SPENDOLINI, M.J. Benchmarking. São Paulo: Makron Books, 1993.

(TJRN, 2009). Resolução No 065/2009, de 15 de dezembro de 2009. Resolução Interna do Tribunal de Justiça do RN. Sítio eletrônico - tjrn.jus.br. Acesso em: 17 maio. 2014.

TORRES, M.D.de F.. Estado, democracia e administração pública no Brasil. Rio de Janeiro: Fundação Getúlio Vargas, 2004. p. 175.

VERGARA, S.C.. Métodos de Pesquisa em Administração. São Paulo: Atlas,2005.

WARHLICH, B. M. S. A reforma administrativa no Brasil: Experiência anterior, situação atual e perspectivas - uma apreciação geral. Revista de Administração Pública, jan./mar, Rio de Janeiro, 1984. 